\title{
People Perception of Waste Management in Malaysia
}

\author{
*Shinta Melly ${ }^{1}$ and Nur Syafawani Binti Azman² \\ ${ }^{1)}$ Graduate Student of Geography Education, Universitas Negeri Padang, Indonesia \\ e-mail: shintamelly03@gmail.com \\ 2) Student of Geography, Malaya University, Malaysia \\ e-mail: syafawaniazman96@gmail.com
}

${ }^{*}$ Corresponding Author, Received: September 14, 2018, Revised: October 21, 2018, Accepted: December 05, 2018

This is an open acces article distributed under the Creative Commons 4.0 Attribution License, wich permits unrestricted use, Distribution, and reproduction in any medium provided the original work is properly cited @2017 by author and Universitas Negeri Padang

\begin{abstract}
Perception in relation to the environment, which is process by individuals organizes and interpret the impression of their senses to give meaning to their environment. With the perception, attitude will be formed which stable tendency to act in certain situations. The purpose of this study is to find out the perception of the people in Malaysia towards to waste management which seen from the role of the people in waste management, the motivation of the people to participate and the activities of people participation in waste management. This type of research is descriptive qualitative using observation, interview, and documentation study techniques in data collection. The results of the analysis of this study area) public perception of waste management in Malaysia b) efforts made by the government in relation to waste management in Malaysia c) impact of increasing waste production in Malaysia.
\end{abstract}

Keywords: Waste, Perception, Waste Management

\section{Introduction}

Environmental management which integrated into community activities cannot be separated from the body and community participation. In this case, quantity and quality, forms of roles and functions in increasing ability and responsibility, they can receive, process, and shorten and incorporate the nature of their mind, as well as the information and stimulate the movements to receive. Good environmental management activities related to environmental management activities. Environmentally sound management and development are conscious and planned efforts to use and manage resources wisely to improve the quality of life that is planned and sustainable. The implementation of environmentally sound development and controlled utilization of natural resources wisely are the main objectives of environmental management (Hermon, 2010). A planned environmental management illustrates how the sustainability of the environmental balance and carrying capacity of the environment is able to reduce the occurrence of environmental risks that can create problems in environmental management (Umar and I. Dewata, 2017; Hermon, 2017; Hermon et al., 2018).

Beside by Moskowitz and Orgel (Walgito, 1999), perception is the process of organizing, integrating stimulus received by individuals or individuals which something meaningful and activity integrated within individuals. Through individuals who can access, can understand the state of the existing environment and can be shaken in the stimulus can be accessed from outside the individual as well. If what they perceive their self as an object of perception, this is what is called self-perception. Because in perception it is an integrated activity, then everything in a person such as feeling, experience, ability to think, 
measurement and other aspects that exist in individual will take part in that perception (Indrawijaya, 1989; Davis, 1995; Gibson, 1996; Triyadi, 2006; Wangke, 2010; Anonim, 2011; Hermon, 2016)

Perceptions of each individual needed to contribute the performance needed to improve reliable abilities and provide reliable information individually. Furthermore, it is used foster motivation to be better and willing to be used in natural resource management and environmental exploration (Azwar, 1996; Desbiens, 1999; Entjang, 2000; Widyatmiko, 2002; Anwar, 2003; Chandra, 2007).

Environmental problems are problems that will continue to develop and process. One of the environmental problems that are very close to everyday life is the problem of waste. Various results from human activities and the increasing number of population resulted in more and more waste materials (Chandra, 2006; Hermon, 2010; Hermon, 2012; Hermon, 2015). Waste is an often a complicated problem in society, waste can also be an opportunity for environmental pollution and a decrease in environmental quality. Therefore, it is necessary to have environmentally sound waste management with the main objective of reducing waste and utilizing waste so that it does not become a truly useless and discarded item (Sugiarto, 1987; Slamet, 2000; Wardhana, 2001; Suarna, 2008; Anonymous, 2011).

At present, the problem of waste is an important issue that requires proper handling. Population growth and changes in community consumption patterns lead to an increasingly diverse volume, type and characteristics of the waste. The use of packaging in the form of paper, plastic, cans, and other materials is still high which can cause an increase in the amount of urban waste generation by 2-4 percent / year. However, this was not followed by adequate facilities and infrastructure problems so that waste that was not handled became one of the sources of environmental pollution (Status of the Indonesian Environment, 2004).

According to Peraturan Republik Indonesia Nomor 18 Tahun 2008 concerning Waste Management, it is explained that the condition of waste management in Indonesia is generally not in accordance with waste management methods that are environmentally sound so that they have a negative impact on public health and the environment. For this reason, waste has become a national problem so its management needs to be carried out comprehensively and integrated from upstream to downstream so as to provide economic benefits, be healthy for the community and safe for the environment and can change people's behaviour.

Increasing the volume of waste has a direct impact on the capacity of temporary waste management facilities available, if it is not managed properly, it can adversely affect the beauty and environmental sanitation. Waste is a consequence of human activities, and human activities must produce waste or waste. The volume of waste produced is usually proportional to the level of consumption of goods/materials used daily. Increasing the volume of waste is usually in tune with population growth and is also influenced by several factors such as increasing the intensity of daily activities, technological advances, especially in product packaging systems and lifestyle changes that tend to choose fast and practical. The more waste that is disposed of, it is certain that waste becomes more diverse and there are many types of materials that are not biodegradable easily. Waste management has so far been using the 'get rid of dump' pattern, but this step has proven to be less capable in solving waste problems in urban areas, but only moving problems from urban areas to waste disposal areas outside urban areas (Kusnoputranto, 1993; Salim, 1995; Saleh, 2010; Notoatmojo, 2011).

The problem of waste in Indonesia has become a problem that is often experienced. In a period of twenty years, solid waste generated from domestic and commercial activities has been confusing to almost all local governments in Indonesia. DKI Jakarta for example, with a population of around 8.5 million people, until now it still has to deal with the pressure of producing waste which reaches more than 800 tons/day. Various handling efforts have been carried out, but have not been able to solve the problem that is increasingly urgent and even tends to create new problems for the deployment area of the city chosen as the location of Final Disposal Sites (Sarwono, 1987; Soemarwonto, 1994; Yakkin, 2004; Setiawan, 2008).

As with other developing countries, Malaysia is also faced with the problem of increasing waste production and its disposal efforts. With a population of 24 million, Malaysia produces around 16,000 tons of domestic waste per day. Common problems that occur are waste collection services are very inefficient, do not have an environmental control system, poor operational technical implementation, still apply open burning dumping, mushrooming illegal waste disposal sites, and low level of public awareness in handling waste (Nazir, 1999; Patista, 2001; Lau, 2004). Therefore, it is necessary to have an environmentally sound 
waste management accompanied by a decrease in environmental quality. Therefore, it is necessary to have an environmentally sound waste management with the aim of reducing waste and utilizing waste so that it does not become a truly useful item and is not disposed.

\section{Method}

This research is descriptive qualitative research using observation, interview, and documentation study techniques in data collection (Hermon et al., 2008). The type of data used is primary data and secondary data obtained from the people in Malaysia. Primary data is collected by interviewing resource people and conducting observations or open observations related to public perceptions of waste management, internet searches related to waste management information, as well as documents that have been published by relevant agencies.

\section{Results and Discussion}

Increasing the volume of waste has a direct impact on the capacity of temporary waste management facilities available, if it is not managed properly, it will adversely affect the beauty and environmental sanitation. Waste is a consequence of human activities, every human activity must produce waste or waste. The volume of waste produced is usually proportional to the level of consumption of goods/materials used daily. Increased waste volume is usually in tune with population growth and is also influenced by several factors such as increasing the intensity of daily activities, technological advances, especially in product packaging systems and lifestyle changes that choose fast and practical.

The problem of waste is a classic problem experienced by almost all major cities, even in other developing countries. Technically, the handling of waste starts from the segregation stage at the household level or the place of business, until the final disposal stage can no longer be carried out partially but must be integrated. To deal with the problem of waste as a whole, it is necessary to conduct management alternatives. These alternatives must be able to deal with the problem of waste disposal by recycling all waste that is disposed of back to the community's economy or to nature, so as to reduce pressure on natural resources.

As with other developing countries, Malaysia is also faced with the problem of increasing waste production and its disposal efforts. With a large population and various other common problems, one of which is about waste, the Malaysia government must be efficient in dealing with waste problems. Common problems that occur are waste collection services are very inefficient, do not have an environmental control system, poor operational technical implementation, still apply open burning dumping, mushrooming illegal waste disposal sites, and low levels of public awareness in handling waste. In the internal scope of the government, the problem of coordination between agencies is very weak, the obscurity of the functions of each sector and the burden of allocating costs for waste management and processing which reaches almost $50 \%$ of the regional government operational budget. To deal with the problem, Malaysia government then handed over the task of waste management to private parties.

In 1993, Malaysia government initiated a waste management privatization program that began by preparing a privatization plan for waste management for each stage of activities, including collection, collection, transportation, processing and disposal of waste. This policy was issued as an effort to create a system of waste management in an integrated, planned, well-managed, efficient and effective manner, by utilizing high technology that focuses on reducing waste and using technology for recycling processes starting at the household level, the next government's role is too strict supervision so that the appointed private company continues to meet the quality, standards and regulations set by the government.

In 2018, waste management has been well managed, as evidenced by waste management in several places that have received effective and efficient management which is seen from the presence of landfills located around the location. There is a role of the government in dealing with the problem of waste, as evidenced by the establishment of the "River of Live" program that has been going well. This program is more concerned with the surrounding environment, especially in the river area. The components that are formed are river cleaning, river removal, and the role of ministries both in the provision of funds and in the role of guarding the development around the river. 
The "River of Live" program was formed due to the lack of public awareness of waste disposal. So that the government anticipates waste problems properly so that there will be no flooding due to the dumping of waste directly into the river. The government handles this problem so that waste management can be formed effectively and efficiently. Handling given in the River of Live program prioritizes overcoming the problem of flooding because floods are formed from scattered waste and go straight to the river. In overcoming flooding, several ponds are made so that the water that flows in the river can flow in all directions so there is no congestion, as well as fostering new structures around the river and changing the state of the river flow. In addition, it often cuts the grass around the pond that is made and makes stone nets around the pond and river to help prevent the waste flowing in the river. In the River of the Live program, it also pays attention to the development of buildings around the river, meaning that around the river does not do development which can cause obstruction of the distribution of water flow.

In this River of the Live program, the government pays attention to the situation of places around the layout of Malaysia. Especially the Gombak river, Klang river, Kerayong river, and Batu river where there is a river where there is still waste and kitchen waste or community waste that flows around the river. With the government program in River of Live, this has helped a lot in environmental cleanliness, especially the management of effective and efficient.

Waste management that has been implemented or is still in the development stage is that the government pays attention to places so that the existing waste is managed properly. Near the market, it was made RWTP which meant that the blood of ex-slaughter was made in its disposal and there was also a waste dump in the form of neatly managed barrels. Floating (bridge) is made to be able to filter waste, JKT is made (place of oil / liquid disposal that cannot be destroyed with water).

In addition, the efforts made by the local government are by improving the cleaning service system. Where the community whose location is already affordable by the waste management service by the local Sanitation Department to be able to dispose of waste at the TPS provided. Communities whose location is not yet covered by Government services are encouraged to carry out their own management by accommodating waste in certain places then burning or stockpiling directly. As well as improvements in facilities and infrastructure where visible waste management has been placed in several places.

\section{Conclusion}

By local media, the privatization program in Malaysia is considered to have been able to create a more efficient waste management system in terms of operational aspects. But that does not mean that the problem of waste management in the country has been completely overcome. Meanwhile, the management of toxic and hazardous waste management is left to a private consortium in charge of operating a centre for toxic waste treatment facilities which are under the authority and closely monitored by the Ministry of Environment at the central and regional levels. In an effort to reduce industrial waste production, Malaysia government issued tax breaks for industries that use environmentally friendly technology and promote the industry to process and reuse its products and packaging. But Malaysia government also urges people to be more concerned about the surrounding environment so that there will be no waste decay everywhere.

\section{References}

Anderson, E. G. 1998. Privating Management of Solid Waste in Developing Countries. The Malaysia Experience

Anonim. 2011. Bank Sampah dan 3R: Membangun Lingkungan dan Ekonomi Kerakyatan, Kementrian dan Lingkungan Hidup Republik Indonesia: Jakarta

Chandra, B. 2006. Pengantar Kesehatan Lingkungan. EGC:Jakarta

Davis. K and J.W Newstrom. 1995. Perilaku dalam Organisasi Edisi Ketujuh terjemahan. Jakarta:Erlangga

Gibson. J and Donnely J.R 1996. Organisasi, Perilaku, Struktur, Proses Edisi 8 Jilid 1 Terjemahan.Jakarta: Binarupa Aksara 
Hermon, D., Khairani., Daswirman., S. Karim., Dasrizal., and Triyatno. 2008. Metode dan Teknik Penelitian Geografi Tanah: Aplikasi Instrumen dan Acuan Penelitian Geografi Fisik. Yayasan Jihadul Khair Center.

Hermon, D. 2010. Geografi Lingkungan: Perubahan Lingkungan Global. UNP Press.

Hermon, D. 2012. Mitigasi Bencana Hidrometeorlogi: Banjir, Longsor, Degradasi Lahan, Ekologi, Kekeringan, dan Puting Beliung. UNP Press. Padang.

Hermon, D. 2015. Geografi Bencana Alam. Jakarta: PT RajaGrafindo Persada.

Hermon, D. 2016. Mitigasi Perubahan Iklim. Rajawali Pers (Radjagrafindo).

Hermon, D. 2017. Climate Change Mitigation. Rajawali Pers (Radjagrafindo).

Hermon, D., Y. Suasti., Ernawati., Afdhal., and H. Edial. 2018. Geografi: Geografi untuk SMU. Jurusan Geografi Universitas Negeri Padang.

Iswandi U and Dewata, Indang. 2017. Pendekatan Sistem dalam Ilmu Sosial, Teknik dan Lingkungan. PT Raja Grafindo Persada. Depok

Indrawijaya, A. 1989. Perilaku Organisasi.Cetakan Keempat. Bandung:Sinar Baru

Lau, L. 2004. Case Study on The Management of Waste Materials in Malaysia. Southern Waste Management SDN.BHD. http://www.swmsb.comSugiyono, 2012. Metode Penelitian Bisnis (Pendekatan Kuantitatif, Kualitatif, dan R\&D). Alfabeta:Bandung

Nazir, M. 1999. Metode Penelitian. Jakarta: Ghalia Indonesia

Patista, A. 2001 Aplikasi SPSS dalam Statistik dan Rancangan Percobaan. Bandung: Alfabeta

Slamet, J.S. 2000. Kesehatan Lingkungan. Yogyakarta: Gadjah Mada University Press

Suarna, I.W. 2008. Model Penanggulangan Masalah Sampah Perkotaan dan Pedesaan, Denpasar: Pusat Penelitian Lingkungan Hidup Universitas Udayana

Sugiyono. 2012. Metode Penelitian Bisnis (Pendekatan Kuantitatif, Kualitatif dan R\&D). Alfabeta:Bandung

Triyadi, S dan Andi H.S. 2006. Tempat Sampah, Perilaku Manusia dan Pembangunan Berkelanjutan. Jurnal Teknik Lingkungan. Edisi Khusus Agustus 2006

Wangke, W. 2010. Persepsi Masyarakat Terhadap Kegiatan Pengembangan Lapangan UAP dan PLTP Unit 5 dan 6 PT Pertamina Geothermal Energy: Jurnal Agri-Sosioekonomi. Vol.6, No.3:39-44

Widyatmiko. G.H and Sintorini. 2002. Menghindari, Mengolah, dan Menyingkirkan Sampah. Jakarta: PT. Dinastindo Adiperkasa Internasional

Wardhana, W.A. 2001. Dampak Pencemaran Lingkungan (Edisi revisi), dengan Kata Sambutan Mentri Negara Lingkungan Hidup/Kepala BAPEDAL. Yogyakarta: Andi. 